\title{
Contemporary trends in Japanese business environment: A review of existing empirical evidence
}

\author{
Michaela Blahováa ${ }^{\mathrm{a}, *}$, Přemysl Pálka ${ }^{\mathrm{a}}$ and Milan Zelenýa ${ }^{\mathrm{a}, \mathrm{b}}$ \\ ${ }^{a}$ Tomas Bata University in Zlín, Czech Republic \\ ${ }^{\mathrm{b}}$ Fordham University, GBA, NY, USA
}

\begin{abstract}
The main purpose of this paper is to identify current trends and practices that have been influencing Japanese business environment and their consequences to corporate world by conducting a review of existing empirical evidence on this topic. An in-depth review of more than 1,600 articles published in high-quality academic journals in the areas of Business Management, Accounting, Social Sciences, Engineering, Economics, Econometrics, Operations Research Management Science, Psychology, Public Administration, Finance and Decision Sciences was pursued following a multiple-step process. Furthermore, the trends were classified into six categories based on their occurrence frequency and described in detail. These trends involve: reformulating strategic management principles, less lifelong employment orientation and change of traditional HRM practices, raising labour force participation, female participation in management and improving education, use of non-financial performance indicators, decomposition of a large organization into smaller units and opening up to outside influence. Each of the categories contained specific practices that interacted with each other, shaping and giving strength to each individual category. Finally, the insights extracted from the literature review were synthesized and directions to future research were provided.
\end{abstract}

Keywords: Trends, Japan, business, management

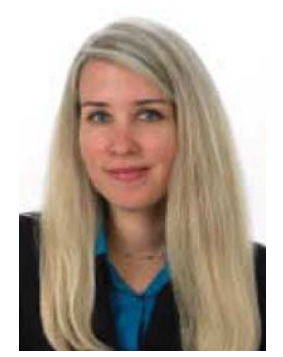

Michaela Blahová $(\mathrm{PhD}$, Tomas Bata University in Zlín, Czech Republic)

is a researcher at the Centre of Applied Economic Research of the Faculty of Management and Economics. Her research interests include corporate finance, management and measurement of performance of companies and modern managerial concepts influencing corporate performance. Currently, she deals with contemporary trends in different management systems and their consequences to corporate world. She is a leader of a research project supported by the Czech Science Foundation focused on creating strategic performance model framework based on utilization of synergy effects of selected management systems and has had experience with various international projects, too.

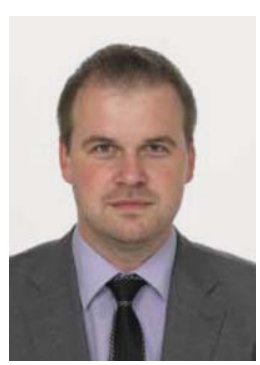

Přemysl Pálka (PhD, Tomas Bata University in Zlín, Czech Republic) is an academic and Vice-Dean for international relations at the Faculty of Management and Economics. His research interests include corporate finance, business valuation, value based management and measurement of performance of companies and modern managerial concepts influencing corporate performance. He has been an investigator/co-investigator of different research as well as educational projects.

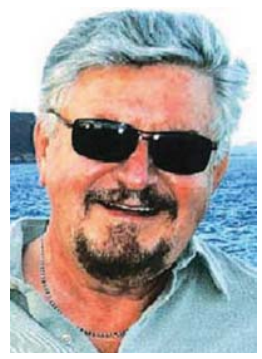

Milan Zelený, Professor of Management Systems at Fordham University, New York City, has been recently ranked No. 1 among Czech economists, according to Hirsch citation index. In his new book Human Systems Management: Integrating Knowledge, Management and Systems, World Scientific, 2005 (2nd edition 2012), he summarizes knowledge as purposeful coordination of action and its implications for the global economics and management.

Recently also a Visiting Professor at Tomas Bata University in Zlín,

*Corresponding author: Michaela Blahová, Tomas Bata University in Zlín, Czech Republic. Tel.: +420 576032 509; E-mail: mblahova@fame.utb.cz.
Czech Republic, Xidian University in Xi'an, Fu Jen University in Taipei, Indian Institute of Technology, Kanpur, and IBMEC, Rio de Janeiro. Among recently published books are Information 
Technology in Business (Thomson International), New Frontiers of Decision Making for the Information Technology Era (World Scientific). Currently working on The Biocycle of Business: Managing Enterprise as a Living Organism.

Zelený has served as the Editor-in-Chief of Human Systems Management for 30 years and is on editorial boards of International Journal of Information Technology and Decision Making, International Journal of Mobile Learning and Organization, Prestige Journal of Management and Research, Economics and Management, Information and Operations Management Education, International Journal of Multicriteria Decision Making (IJMCDM) and International Journal of Innovation and Learning, Strategic Decision Sciences, etc. Earlier books include Multiple Criteria Decision Making (McGraw-Hill), Linear Multiobjective Programming (Springer-Verlag), Autopoiesis, Dissipative Structures and Spontaneous Social Orders (Westview Press), MCDM-Past Decades and Future Trends (JAI Press), Autopoiesis: A Theory of the Living Organization (Elsevier North Holland), Uncertain Prospects Ranking and Portfolio Analysis (Verlag Anton Hain), Multiple Criteria Decision Making (University of South Carolina Press) and Multiple Criteria Decision Making: Kyoto 1975 (Springer-Verlag).

\section{Introduction}

Japan belongs to the most influential economies in Asia and is after the USA and China the third largest economy in the world (World Economic Outlook, International Monetary Fund). It is home to many major corporations, leading-edge technology, operational knowhow, and a strong currency [49, 54, 86, 88].

The success of Japanese companies in the world markets since the 1970s and 1980s has attracted widespread attention based on such phenomena as production methods, culture, corporate governance and HRM practices $[10,30,40,42,72,76,78,81,83,87,99]$. What became known as the Japanese management model was the first non-Western model to question the supremacy of Western approaches to management, and its principles and practices were imitated in many ways in a number of other Asian countries, such as South Korea, Taiwan and Singapore. But "learning from Japan" was not only a phenomenon limited to Asian nations. Many Western corporations also adopted several aspects of Japanese management, particularly with regard to production processes, and Japanese management developed into a sub-discipline of management studies [78].

However, after a great boom in the 1970s and 1980 s, in the 1990s and the 2000s the Japanese management system started to be considered to be a model of the past [75]. Numerous factors have con- tributed to this, including the long-lasting stagnation of the Japanese economy, ill-advised macroeconomic policies, delayed microeconomic reforms, delayed corporate restructuring, the introduction of new technologies, globalization-induced changes in the international competitive environment, the entry of new competitors that are aping Japanese management practices, socio-demographic developments or changes in the value system of Japanese society.

Even when the Japanese economy started to recover at the beginning of the century, the image of Japanese management did not improve. At the same time, the interest of Western researchers also seemed to have shifted away from Japanese management. Lifetime employment, the seniority system, and group-oriented decision-making have been strongly criticized as holding Japanese companies back for a long time $[6,32,38$, 44, 50, 55, 63, 77-80, 84].

Although the traditional Japanese management model has been perceived by many observers as being in a crisis, the Japanese companies seem to have already overcome the major difficulties. They have been succeeding in combining a new focus on strategy, profit orientation, global outlook and flexibility with their traditional strengths of efficient processes, quality orientation, attention to detail and the capacity to win a substantial degree of loyalty from their employees. As a consequence, Japanese companies are much more powerful competitors than ever before and achieve improved corporate performance.

The main aim of this paper is to integrate our knowledge on the development of traditional Japanese management system over the past decades and on recognizing contemporary trends in the Japanese management practices and their consequences to corporate world by conducting a review of the existing empirical evidence on this topic. The findings shall answer questions related to Japanese management practices that have not been affected by the changes of Japanese management system during the "lost decades" as well as to practices that have recently been adopted by Japanese companies from Western management systems.

By virtue of the research of acquirable resources and findings, the following research question has been set: Is it possible to determine contemporary trends affecting Japanese business environment of today?

\section{Methodology}

To meet our research objectives, the literature review following a multiple-step process has been performed. 
First, we searched the literature and identified the relevant journals for our review. Second, we selected a list of empirical papers that focus on Japanese management practices as well as contemporary trends in Japanese business environment. Third, we chose those papers/studies that met our specific selection criteria. Fourth, we read the papers selected and developed a list of trends and their consequences on corporate world. Fifth, we classified the trends and synthesized the insights extracted from the literature review in order to answer the research question.

Our first step in the literature review process was to identify keywords that could help us to find relevant papers or studies. As we wanted to be precise and were particularly interested in Japanese management, its practices utilized in companies as well as current trends having impact on the global world, we selected Japanese management as the keywords to be involved in the title of the paper.

After that, we searched the literature in two electronic databases, namely ISI Web of Knowledge and SCOPUS, using the keywords selected. We conducted our searches in two different databases to maximize our likelihood of finding relevant studies and to improve the reliability of our research. The review took into consideration published work from 1945 to 2014 (ISI Web of Knowledge) and 1960 to 2014 (SCOPUS). 1,655 papers (868 in ISI Web of Knowledge, 787 in SCOPUS) were identified, downloaded and their abstracts were read.

\subsection{ISI Web of Knowledge}

The first ten research areas in the ISI Web of Knowledge included Business Economics (379), Engineering (96), Operations Research Management Science (47), Psychology (46), Cardiovascular System Cardiology (38), Computer Science (36), Environmental Sciences Ecology (36), Social Sciences Other Topics (36), Area Studies (33) and Public Administration (28). For further investigation we included in the research areas that focused on Business Economics, Engineering, Operations Research Management Science, Psychology, Social Sciences Other Topics, Area Studies, Public Administration, International Relations and Asian Studies as we wanted to concentrate on management and business areas mainly. Therefore, a total number of analyzed articles decreased from 868 to 530 .

The majority of papers included in the ISI Web of Knowledge were articles (253). The other categories involved book reviews (130), proceedings papers (94), editorial materials (21), book chapters (21), letters (21), reviews (9), meeting abstracts (8), books (3) and a note (1).

The key journals identified within the research in the ISI Web of Knowledge were: Harvard Business Review, Journal of Management Studies, Japanese Economic Studies, International Journal of Human Resource Management, Business History, Pacific Affairs, International Journal of Technology Management, Japanese Management in the Low Growth Era, Journal of International Business Studies and Columbia Journal of World Business.

The key authors identified within the research in the ISI Web of Knowledge were: Gautschi, Bird, Niwa, Tsuda, Asakawa, Lynn, Morris, Beechler and Daniel. The majority of papers came from USA (160 records) and Japan (152 records) followed by England (57 records) and Australia (15). 98\% of all articles were published in English.

The highest number of papers included in the ISI Web of Knowledge was published in 2009 and 1981, followed by 1993 .

The citations in the ISI Web of Knowledge were the highest in 2011, followed by 2012 and 2010. The total number of citations reached 2,442, the total number of citations without self-citations got to 2,303.

\subsection{SCOPUS}

The first ten research areas in the SCOPUS included Medicine (324), Business, Management and Accounting (169), Social Sciences (92), Engineering (81), Economics, Econometrics and Finance (78), Agricultural and Biological Sciences (69), Environmental Science (56), Computer Science (36), Decision Sciences (34) and Earth and Planetary Sciences (30). For further investigation we included in the research areas that focused on Business Management and Accounting, Social Sciences, Engineering, Economics, Econometrics and Finance and Decision Sciences as we wanted to concentrate our research primarily on management and business areas mainly. Therefore, a total number of analyzed articles decreased from 787 to 306.

The majority of papers included in the SCOPUS were articles (208). The other categories involved conference papers (47), reviews (22), book chapters (8), erratum (2), editorials (2), articles in press (2), a note (1) and undefined types (14).

The key journals identified within the research in the SCOPUS were: International Journal of Human Resource Management, International Journal 


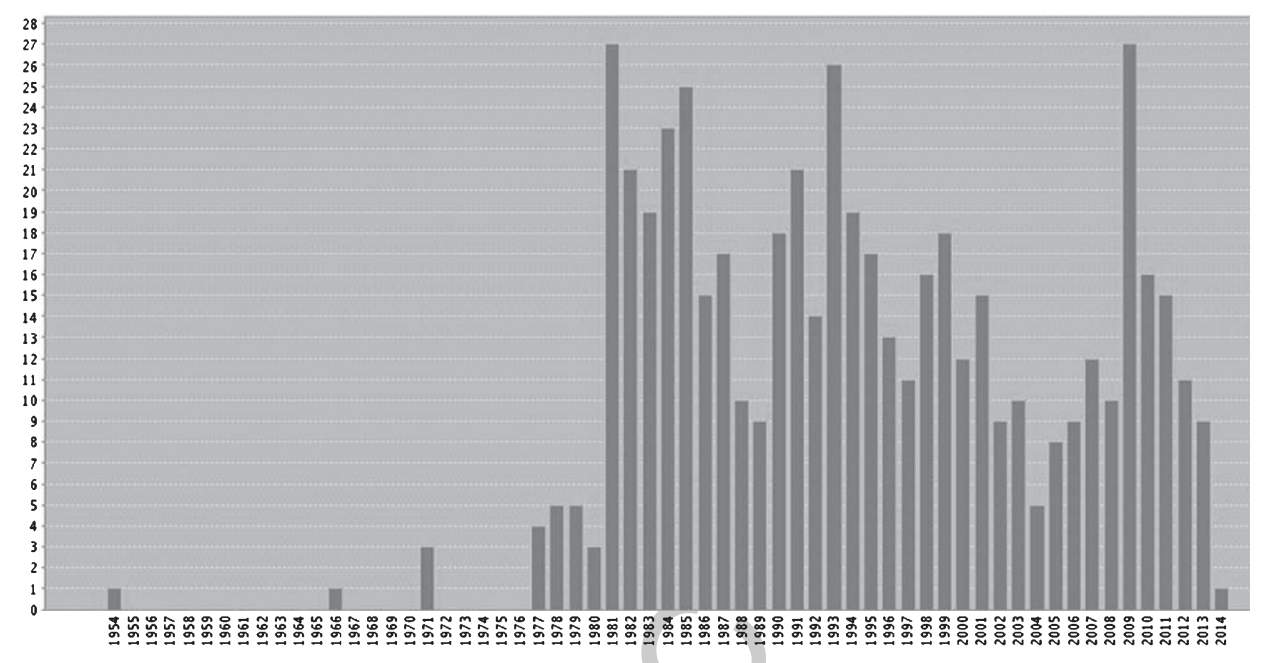

Fig. 1. Published items in each year-ISI Web of Knowledge.

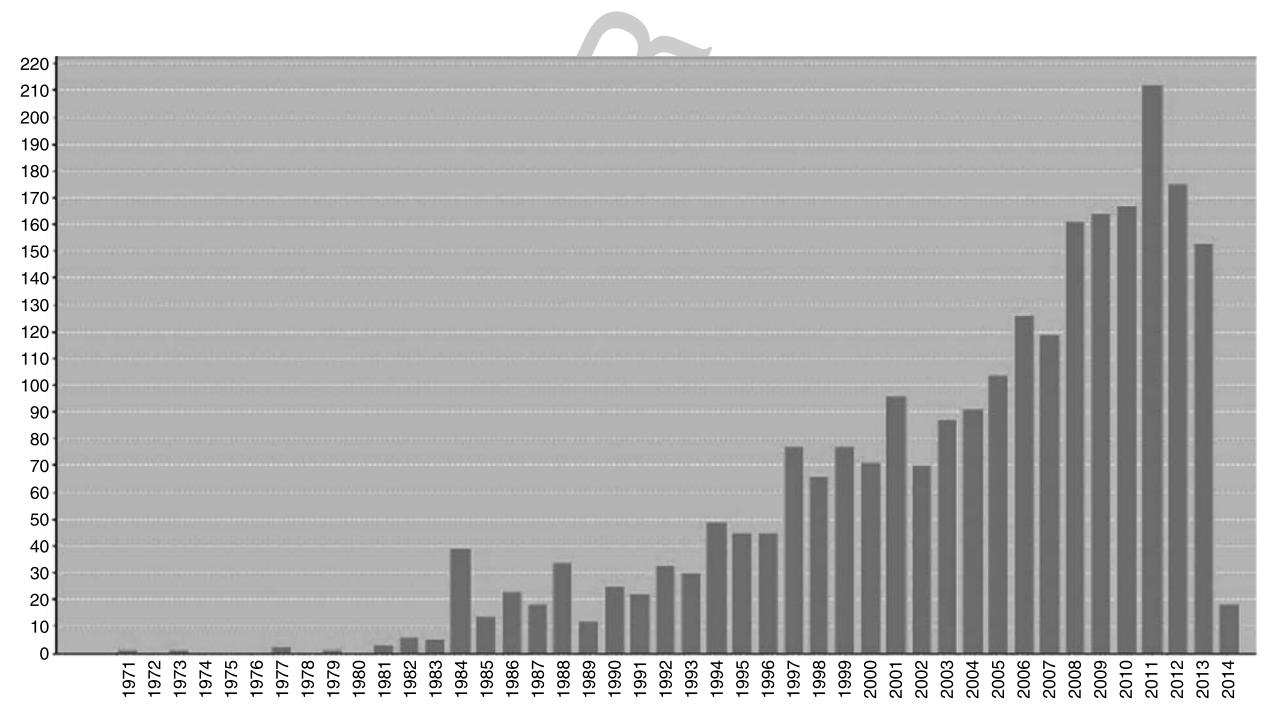

Fig. 2. Citations in each year - ISI Web of Knowledge.

of Technology Management, Asia Pacific Journal of Management, Asia Pacific Business Review, Business Horizons, Long Range Planning, Organizational Dynamics, Management Accounting Research, Marine Policy and Journal of Management Studies.

The key authors identified within the research in the SCOPUS were: Niwa, Asakawa, Haak, Daniel, Reitsperger and Shirahada. The majority of papers came from Japan (135 records), USA (62 records) and UK (22 records).

The highest number of papers included in the SCOPUS was published in 2011, followed by 2009 and 2007. A total number of 1797 citations were received since 1996 (SCOPUS does not have complete citation information for articles published before 1996).

After reading the abstracts, we selected papers that met our selection criteria and downloaded them. The criteria are described as follows:

- We chose 20 journals as the main source of our research. Based on the analysis performed and described earlier, we selected top 10 key journals from the ISI Web of Knowledge database and top 10 key journals from the SCOPUS database. 3 journals were included in both databases, 
namely International Journal of Human Resource Management, International Journal of Technology Management and Journal of Management Studies. The selected journals were: International Journal of Human Resource Management, International Journal of Technology Management, Asia Pacific Journal of Management, Asia Pacific Business Review, Business Horizons, Long Range Planning, Organizational Dynamics, Management Accounting Research, Marine Policy, Journal of Management Studies, Harvard Business Review, Japanese Economic Studies, Business History, Pacific Affairs, Japanese Management in the Low Growth Era, Journal of International Business Studies and Columbia Journal of World Business. We selected these journals because they are the more likely to publish research articles on Japanese management. Moreover, they are also regarded as being of top quality within each of the disciplines included in the review.

- As the majority of papers were published as articles, we took this document type into consideration only. In total we examined 253 articles included in the ISI Web of Knowledge and 208 articles included in the SCOPUS database.

\section{Findings}

In this section we present our findings of the research that has examined contemporary trends and relevance of Japanese management practices to managers, policymakers and academic researchers. Since the emergence of the Japanese model in the 1980s, important changes have been made in the management practices of Japanese firms. The purpose of the research was to identify key changes and trends that have been influencing Japanese companies so far.

We collected information about contemporary practices that have been believed to be the most important for Japanese business environment. From the analyses we identified six categories that were recurring themes across the research sample. These categories are seen as key trends that have occurred within the Japanese management techniques recently and thus represent a valuable contribution both to research and practice:

- Reformulating strategic management principles

- Less lifelong employment orientation and change of traditional HRM practices
- Raising labour force participation, female participation in management and improving education

- Use of non-financial performance indicators

- Decomposition of a large organization into smaller units

- Opening up to outside influence

Each of these categories, however, contained specific practices that interacted with each other, shaping and giving strength to each individual category. A few other trends occurred within the research, however, their occurrence frequency was rather low, and therefore, we did not involve them into our summary. The next six sections describe the findings in detail.

\subsection{Finding 1: Reformulating strategic management principles}

The research showed that since the late 1990s many Japanese firms have sought performance gains through the implementation of widespread changes to governance mechanisms, corporate structures, labour relations and employment practices $[9,21,24,57,74$, 85, 89].

A number of studies [27, 38, 50, 63, 68, 97] have attempted to examine whether and how Japanese companies have changed over past years in terms of business strategies, organizational structure and corporate governance.

Sakikawa [84] presents in his book the transformations of Japanese companies and workplaces that have taken place since the turn of the twenty-first century in terms of management practices and organizational culture. Some scholars (e.g. Jacoby [48]) have examined the same issues, including human resource management (HRM), but mainly on policies formulated by HRM staff employees in company headquarters or by people in high-ranking positions within an organization.

Other researchers (e.g. Phan et al. [74]) have directly investigated relationships between quality management practices and competitive performance in Japanese manufacturing companies between 2 periods (1990s and 2000s) in order to compare the degree of implementation of selected quality management practices and their impact on different dimensions of competitive performance.

Pudelko and Mendenhall [80] in their research found out that Japanese companies have been in several ways reformulating what used to be key characteristics of their strategic management principles. One of these changes concerns a shift away from (long-term) market 
share orientation towards more (short-term) profit orientation. It should be noted that even in the 1980s, when Japanese corporations conquered many global markets, the profits of even the most prominent Japanese companies were on average very low, as all energies were focused on growth of market share. However, with the burst of the bubble economy, the generation of cash flow to pay off debts became the dominant objective, out of pure necessity to survive. The old Adam Smith dictum applied painfully to Japanese companies in all sectors: "Long-term views are important, but one can also die in the short-term." This experience seemed to have had a strong impact on Japanese companies and, according to the executives in the research sample, profit generation is likely to remain prominently on their agendas.

Companies start to utilize measures, both radical and benign, that include reforming corporate governance, building partnerships with rivals both at home and abroad, concentrating resources on future promising business areas such as social infrastructures and solar panels, digitizing business transactions, halting new graduate recruitment, and cutting back on the cost of entertaining, Sakikawa [84] emphasizes.

\subsection{Finding 2: Less lifelong employment orientation and change of traditional HRM practices}

There is a strong agreement of researchers [13, 20, $32,39,45,55,64,77,101]$ on the acknowledgement of the perception that typical Japanese management practices, such as lifetime employment and the seniority system, are increasingly being challenged, and there is a trend toward American-style management practices, with far-reaching implications regarding the traditionally tight connections between companies (keiretsu) that are still considered to be too dominant in terms of distribution.

Pudelko and Mendelhall [80] view Japanese companies gradually reinforce individual performance as a key criterion for promotion and compensation, reducing the focus on seniority. They also introduce more flexibility in their recruitment practices.

These findings are shared by Sakikawa [84] who agrees with the statement that with job security intact, at least for regular and core workers, Japanese companies have totally or partially changed the seniority system and have replaced it with the American pay-forperformance style. Pudelko and Harzing [79] found out in their research that several fundamental principles of traditional Japanese human resource management are considerably on the wane - e.g. turning away from lifelong employment, flexibility of recruitment, release of personnel and change of employer, recruitment of experienced specialists for specifically advertised positions, increased formation of specialists and turning away from the formation of generalists, etc.

The changes in employment practices are considered by Keizer et al. [51] as a part of a wider development; moving from long-term relationships towards a greater marketization and internationalization of the Japanese economy set against the backdrop of the prevailing conditions in the global economy. The introduction of performance-related pay means that the basis for remuneration has shifted away from the long-term development of skills towards short-term results. It can be considered as a new standard in the management of regular workers among Japanese firms and has introduced important changes to their evaluation and remuneration. Seniority system remains as a criterion for evaluation, but it no longer defines the Japanese wage system.

\subsection{Finding 3: Raising labour force participation, female participation in management and improving education}

An extensive research performed by McKinsey [93] focused on gender composition in companies in Asia showed that in recent years the numbers of women graduates and of women at entry-level positions in companies have increased although the proportion of women sitting on corporate boards and executive committees in Asian companies is strikingly low compare with Europe and the United States. Japan enacted the equal employment opportunity law (in 1985) but the reality is far from what is stipulated by this law. Japanese society is still highly male dominated and this is especially true at the workplace [13, 56, 104].

Japanese female participation in management is considerably lower than in other industrialized nations [82, 94], despite the fact that the female workforce in Japan is among the most educated in the world [69]. The participation rate of prime-age women (between 25 and 54) rose from $65 \%$ in 1994 to $72 \%$ in 2010 . Nevertheless, it was still the fifth lowest in the OECD area, as around $60 \%$ of female workers still withdraw from the labour force when their first child is born.

The traditional Japanese perspective is that a woman's position in society is primarily that of family 


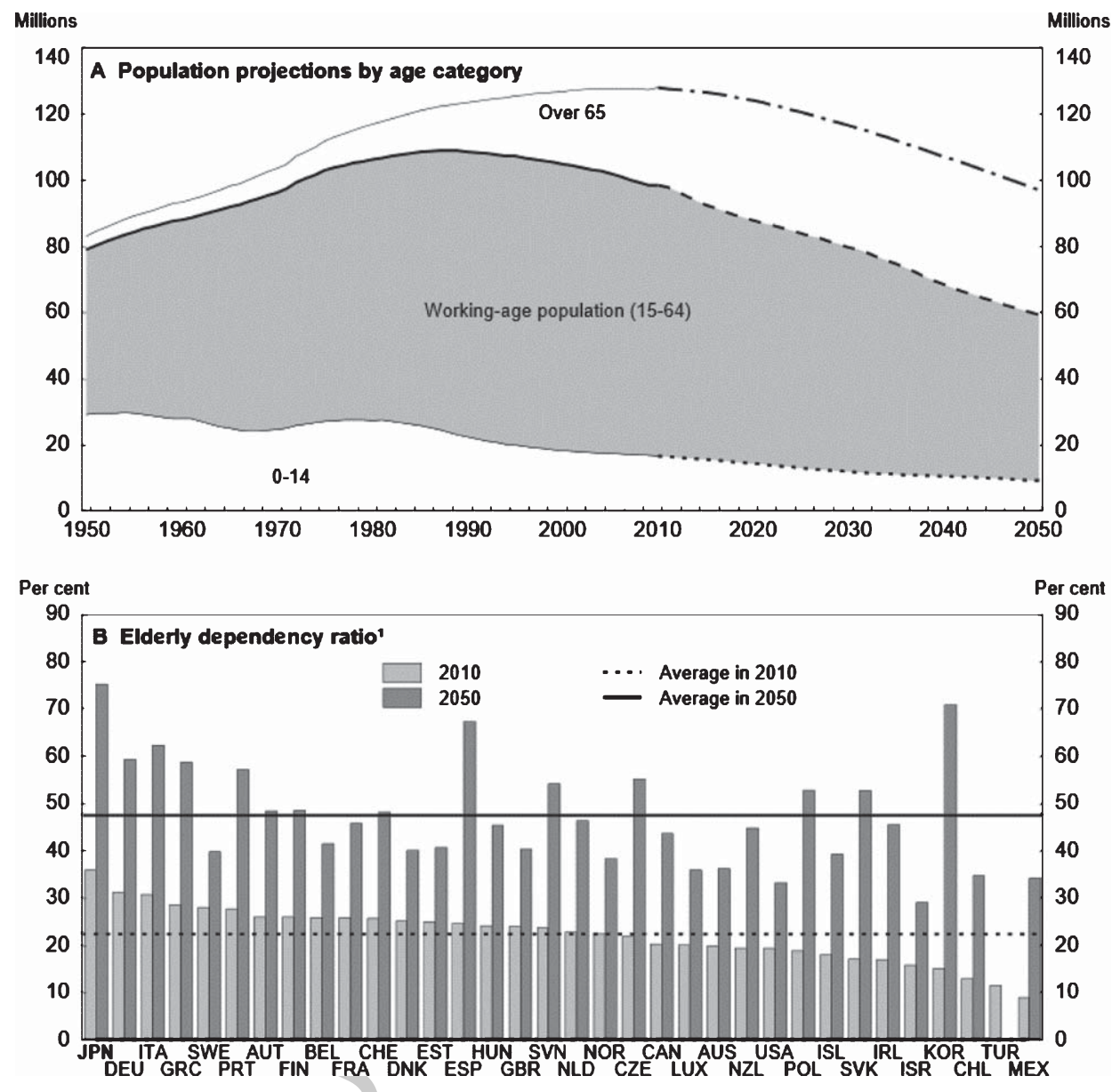

Fig. 3. Japan's population, already the oldest in the OECD, is ageing rapidly [65].

caretaker and mother [98]. Indeed, it has not been uncommon for Japanese to view a woman's participation in the workforce as a temporary stage of her life, with the expectation that she will eventually marry, leave the workforce, and raise a family [92]. Japan's transition toward a more engaged female workforce is currently in progress, necessitated by economic and demographic realities [2].

However, the shifting of cultural values is typically a gradual process, which suggests that this transition will take time. In Japan, there are currently signs of both progress (e.g. workplace regulation reforms, rising university education among women, and increased female political representation) and resistance (e.g. persistent social attitudes and continued underrepresentation of females in management). Foreign-owned organizations are part of the change process, as are some smaller, less traditional domestic firms. The movement away from these essential components of the Japanese HRM model illustrates the degree to which Japanese HRM is in upheaval.

The employment rate for the 60-to-64 age group rose from $53 \%$ in 2006 to $57 \%$ in 2010 , although most firms set mandatory retirement at age 60 [70]. Mandatory retirement is a key element of traditional Japanese labour practices, given that the steep seniority-based wage profile makes older workers expensive. The government has introduced measures to encourage workers to remain longer at firms, including a 2013 law requiring that firms keep all workers who wish to work until 65 , although this increases the risk attached to hiring regular workers, thereby encouraging non-regular employment.

OECD [70] suggests to encourage labour market participation of women, the elderly and youth as follows: 
- Reform aspects of the tax and social security system that reduce work incentives for secondary earners.

- Increase the availability of affordable, high-quality childcare and encourage better work-life balance, in part by reducing working hours and enforcing the Childcare and Family Care Leave Law.

- Reduce labour market dualism, which makes employment less attractive, particularly to women and youth, through a comprehensive strategy that includes upgrading training programmes, increasing the social insurance coverage of non-regular workers and reducing effective employment protection for regular workers.

- Encourage greater use of flexible employment and wage systems to improve working conditions for older workers, in part by abolishing the right of firms to set mandatory retirement at age 60 .

- Encourage practical training, combining on-thejob and classroom learning, in part through expanding the Job Card system, to equip youth with the skills needed in the labour market.

- Improve vocational education, in part by creating a standard qualifications system that is recognized by firms.

Japan is a top performer in education. Nevertheless, educational outcomes, which play a key role in productivity growth, could be improved by greater public investment in pre-primary education, which was the second lowest in the OECD in 2009 [70]. Improving educational outcomes may be reached by e.g. investing more in early childhood education and care to expand and integrate childcare and kindergarten, expanding the autonomy of primary and secondary schools and increasing school choice to encourage schools to excel, improving the quality of the tertiary sector by increasing transparency about performance to strengthen competition, promoting the internationalization of the tertiary sector by increasing the number of foreign students and encouraging the establishment of more foreign tertiary institutions in Japan and enhancing the role of the tertiary sector in innovation, in part through greater cooperation between universities and the business sector, including enhanced labour mobility of researchers.

\subsection{Finding 4: Use of non-financial performance indicators}

Several studies analyzed and confirmed that an increasing number of companies (not only in Japan) have shifted from using traditional financial performance metrics (that are thought to less accurately reflect modern management practices) to measure corporate performance to using non-financial information to increase the effectiveness of performance measurement.

Many researchers are suggesting new approaches to performance management and measurement [11, 12, $14,16,17,19,22,23,34-36,61,66,67,91,107]$.

Various studies that focus on performance measurement confirm that non-financial performance indicators, such as time, quality, operating efficiency, have gained a significant importance in performance measurement in order to moderate the adverse effects of measuring performance using cost information $[6,9$, 18, 21, 33, 58-60].

From a modern production management viewpoint, innovative production management systems, such as JIT and TQM models of control, increase interdependencies among sequential subunits or processes in a factory, and the use of non-financial performance metrics has been shown to be preferable for managing these interdependencies $[1,73,103]$.

\subsection{Finding 5: Decomposition of a large organization into smaller units}

Cooper [26] conceptualized the unique Japanese management practice of a micro-profit centre (MPC), in which lower level shop floor managers were evaluated and rewarded for their performance using profit information. In addition, recent studies have shown that MPC's have been adopted by many Japanese manufacturing companies. For example, a survey by Kijima et al. [52] study of Japanese manufacturing companies listed on the First Section of the Tokyo Stock Exchange showed that MPC's have been adopted by 42.4 percent (39 of 92 companies surveyed).

Similarly, Yoshida et al.'s [100] study of Japanese manufacturing companies listed on the First Section of the Tokyo Stock Exchange showed that 40.4 percent (61 of 151 of companies surveyed) had adopted some form of MPC.

Before Cooper [26] conceived the use of profit information to evaluate small units such as MPC, the Japanese literature [41] had already described unique management practices in production management systems in Japanese factories. They found that factories divided product line processes into small units composed of three to 50 members, with each unit having its own profit calculating system. 
The literature $[3-5,25,43,62,106]$ also explores the consequences of the performance evaluation of MPCs that includes profit information. An example of this is Kyocera corporation, which is one of the most famous companies to have adopted the MPC system in Japan. The company has been studied in depth by both academics and practitioners. Kyocera called this type of management system an "amoeba system".

The use of the word "amoeba" is meant to capture the concept of an entity at its smallest, most elemental level, as well as to describe its life-like capability to "multiply and change shape in response to the environment" [46]. Zelený [105] describes "amoebas" as independent, profit sharing and semi-autonomous teams or departments of three to 50 employees that perform its own statistical control, profit system, cost accounting and personnel management. Amoebas complete, subcontract, and cooperate among themselves on the basis of the intra-company market characterized by real market-derived transfer prices. Main advantages of selected techniques of amoeba system were summarized by Blahová and Zelený [15].

\subsection{Finding 6: Opening up to outside influence}

Haghirian [39] states that Japan has been secluded from foreign markets for many years. This was originally initiated by the third shogun Iemitsu, who - in an attempt to create internal peace and stability - expelled all foreigners and sealed off the country from the rest of the world for about 200 years until 1853 . This period therefore became significant for the development of unique social and business practices - the legacy of which remains a strong pillar in Japanese modern life and business today.

Recent research on Japanese companies has tended to concentrate on internationalization motives and strategies $[13,28,29,31,44,47,53,57,71,90,95,96$, 102].

Japanese companies, particularly those in the manufacturing sector, have made progress toward globalization over the past decade, Sakikawa [84] notes. Japanese manufacturers have transferred production facilities to overseas countries that provide abundant, cheap labour forces so that they can cut costs and be more competitive against their rivals both at home and abroad. Their overseas production has accelerated in recent years as the yen has highly appreciated against the US dollar. Roughly 18 percent of all the products made by Japanese companies in 2010 came from their overseas factories (Nikkei Newspaper, November 4,
2011). This figure is projected to reach over 20 percent in 2015.

However, Japanese companies are increasingly aware that they need to open themselves more toward expertise from the outside $[7,8,37,80]$. They are now increasingly engaging in mergers and acquisitions as a means not only to consolidate industries, but also to inject outside expertise in specific product technologies or processes into the overall organization.

\section{Discussion and conclusions}

The recent world of financial crises and transformation of whole economies have put a lot of pressure on businesses from all sectors and of all sizes. Companies face large social, technological and economic changes where key aspects of competitiveness have moved from data and information to knowledge and wisdom. In order to succeed in today's global market, old strategies need to be re-examined and revised carefully.

Japanese companies have always had an ability to change their strategies rapidly in times of distress and to adapt to a changing environment very fast. This has led to e.g. an integration of new, frequently Western-inspired management principles with traditional Japanese management concepts, and has thus attained a new state of stable equilibrium in which its components are again mutually reinforcing each other, establishing a coherence and consistency within the model itself as well as with the global economic context and the domestic cultural and institutional context. Business management in Japan today is a hybrid of core concepts from the traditional culture and a growing number of Western business practices, and it is continuing to evolve.

Japanese companies have been succeeding in combining a new focus on strategy, profit orientation, global outlook and flexibility with their traditional strengths of efficient processes, quality orientation, attention to detail and the capacity to win a substantial degree of loyalty from their employees.

A number of other significant factors has also helped to determine whether or not Japan remains a worldclass economic power in future, e.g. Japan's ability to develop new technologies, entrepreneurship and wiser and more effective use of female workforce that have been described earlier.

In the literature reviewed above, we identified key trends and practices that have been recently acknowledged by researchers as well as corporate world as main drivers of change of the traditional Japanese 
management model. These features characterize the effort to control costs of production in the global economy where the influence of China, South Korea, Taiwan and other Asian rival countries as centers for cheap manufacturing have undercut many competitors. The ability of these countries to develop cheap, fashionable and fast moving electronics and telecommunication goods has challenged Japanese hegemony in this area.

Current trends that have had an impact on Japanese business environment recently were identified based on an in-depth review of 1,655 articles published in high-quality academic journals in the areas of Business Management, Accounting, Social Sciences, Engineering, Economics, Econometrics, Operations Research Management Science, Psychology, Public Administration, Finance and Decision Sciences.

The literature was searched in two electronic databases, namely ISI Web of Knowledge (868 articles) and SCOPUS (787 articles), using the keywords selected. The research was conducted in two different databases in order to maximize the probability of finding relevant studies and to improve the reliability of our research. The review took into consideration published work from 1945 to 2014 (ISI Web of Knowledge) and 1960 to 2014 (SCOPUS).

The literature review followed a multiple-step process that focused on identification of relevant journals, selection of a list of empirical papers that focus on Japanese management practices and contemporary trends in Japanese business environment, developing a list of trends and their consequences on corporate world, classification of trends and synthesis of the insights extracted from the literature review in order to answer the research question.

The trends were classified into six categories based on their occurrence frequency and described in detail. The following trends were identified within the research:

- reformulating strategic management principles,

- less lifelong employment orientation and change of traditional HRM practices,

- raising labour force participation, female participation in management and improving education,

- use of non-financial performance indicators,

- decomposition of a large organization into smaller units, and,

- opening up to outside influence.

Each of the categories contained specific practices that interacted with each other, shaping and giving strength to each individual category.
As for the first trend that was identified within the research, we can confirm that since the late 1990s many Japanese firms have sought performance gains through the implementation of widespread changes to governance mechanisms, corporate structures, labour relations and employment practices. Several researches found out that Japanese companies have been in several ways reformulating what used to be key characteristics of their strategic management principles. One of these changes concerns a shift away from (long-term) market share orientation towards more (short-term) profit orientation.

The research also showed that typical Japanese management practices, such as lifetime employment and the seniority system, are increasingly being challenged, and there is a trend toward American-style management practices. Japanese companies gradually reinforce individual performance as a key criterion for promotion and compensation, reducing the focus on seniority. Long-term relationships move towards a greater marketization and internationalization of the Japanese economy. The introduction of performancerelated pay means that the basis for remuneration has shifted away from the long-term development of skills towards short-term results.

Moreover, researches on gender composition in companies in Japan showed that in recent years the numbers of women graduates and of women at entry-level positions in companies have increased although the proportion of women sitting on corporate boards and executive committees in Asian companies is strikingly low compare with Europe and the United States. Japan's transition toward a more engaged female workforce is currently in progress, necessitated by economic and demographic realities.

As for elderly employees, the Japanese government has introduced measures to encourage workers to remain longer at firms, including a 2013 law requiring that firms keep all workers who wish to work until 65 , although this increases the risk attached to hiring regular workers, thereby encouraging non-regular employment.

The findings of our research also showed that an increasing number of companies in Japan have shifted from using traditional financial performance metrics (that are thought to less accurately reflect modern management practices) to measure corporate performance to using non-financial information to increase the effectiveness of performance measurement.

More and more companies (particularly in manufacturing sphere) have decomposed their large structures 
into smaller units (often known as micro-profit centres, amoebas, ... ). These units act like independent companies with their own rights and responsibilities that share a united purpose (of their parent company). This leads to an establishment of an effective company acting like a living organism, fast-responding to highly competitive and quickly changing external as well as internal environment that is self-sustainable and auto-poietic.

Last but not least, the research showed that Japanese companies have tended to concentrate on internationalization motives and strategies recently.

\section{Limitations and suggestions for further research}

This paper is not free of limitations. It is based on a literature review method that, despite being systematic and rigorous, might have missed some relevant work that:

- has been published in areas other than Business Management, Accounting, Social Sciences, Engineering, Economics, Econometrics, Operations Research Management Science, Psychology, Public Administration, Finance and Decision Sciences;

- has been published in a journal outside our list of selected journals (International Journal of Human Resource Management, International Journal of Technology Management, Asia Pacific Journal of Management, Asia Pacific Business Review, Business Horizons, Long Range Planning, Organizational Dynamics, Management Accounting Research, Marine Policy, Journal of Management Studies, Harvard Business Review, Japanese Economic Studies, Business History, Pacific Affairs, Japanese Management in the Low Growth Era, Journal of International Business Studies and Columbia Journal of World Business) and has not been referenced by any of the work published in our list of selected journals;

- has been published in lower-ranked journals or in a non-English-language journal.

As for new areas for further research, we emphasize the following. The research that has been described in this paper focused on a literature review of articles available in the ISI Web of Knowledge and SCOPUS databases. New research could further investigate contemporary trends influencing Japanese businesses in other scientific databases in order to broaden the research sample. Moreover, we recommend the results of this research to be verified in real business environment, i.e. qualitative interviews with managers, questionnaire surveys. Last but not least, further attention deserve contemporary trends influencing current businesses not only in Japan but also in other countries in the world. As this area has not been fully explored in the literature so far, further research could advance our understanding in this sphere.

\section{Acknowledgments}

The authors are thankful to the Czech Science Foundation for the grant No. 14-18597P - "Creating Strategic Performance Model Framework Based on Utilization of Synergy Effects of Selected Management Systems" and the Operational Programme Education for Competitiveness co-funded by the European Social Fund (ESF) and national budget of the Czech Republic for the grant No. CZ.1.07/2.3.00/20.0147 - "Human Resources Development in the field of Measurement and Management of Companies, Clusters and Regions Performance", which provided financial support for this research.

\section{References}

[1] M.A. Aberenthy and A.M. Lillis, The impact of manufacturing flexibility on management control system design, Accounting Organizations and Society 20(4) (1995), 241-258.

[2] N. Adler and D. Israeli, Competitive Frontiers: Women Managers in a Global Economy, Oxford: Blackwell, 1994.

[3] R.W. Adler, Performance management and organizational strategy: How to design systems that meet the needs of confrontation strategy firms, British Accounting Review 43(4) (2011), 251-263.

[4] R.W. Adler and T. Hiromoto, Amoeba management: Lessons from kyocera on how to promote organization growth, profitability, integration, and coordinated action, in: Proceedings of the Performance Measurement Association (PMA) Conference of the University of Otago, Dunedin, New Zealand, 2009.

[5] R.W. Adler and T. Hiromoto, Amoeba management: Lessons from Japan's Kyocera, MIT Sloan Management Review 54(1) (2012), 83-89.

[6] K. Arai, H. Kitada and K. Oura, Using profit information for production management: Evidence from japanese factories, Journal of Accounting \& Organizational Change 9(4) (2013), 408-426.

[7] K. Asakawa, K. Ito, E.L. Rose and D.E. Westney, Internationalization in Japan's service industries, Asia Pacific Journal of Management 30(4) (2013), 1155-1168. 
[8] K. Asakawa and D.E. Westney, Evolutionary perspectives on the internationalisation of R\&D in japanese multinational corporations, Asian Business and Management 12(1) (2013), 115-141.

[9] R.D. Banker, G. Potter and R.G. Schroeder, Reporting manufacturing performance measures to workers: An empirical study, Journal of Management Accounting Research 5 (1993), 33-55.

[10] R. Betancourt and D. Gautschi, The economics of retail firms, Managerial and Decision Economics 9(2) (1988), 133-144.

[11] U. Bititci, P. Garengo, V. Dörfler and S. Nudurupati, Performance measurement: Challenges for tomorrow, International Journal of Management Reviews 14 (2012), 305-327.

[12] M. Blahová, Enhancement of companies' performance using right management tools and their influence on corporate strategy, in Proceedings of the 6th European Conference on Management, Leadership and Governance, The College of Management Edukacja and the Professional Development Centre Edukacja, Wroclaw, Poland, 2010.

[13] M. Blahová, P. Haghirian and P. Pálka, Current trends in strategic management and performance measurement: An evidence from Japan, in Proceedings of the International Conference on Performance Management: Designing the High-Performing Organization, Aarhus University, Aarhus, Denmark, in cooperation with University of Cambridge, United Kingdom, 2014.

[14] M. Blahová and A. Knápková, Effective strategic action: From formulation to implementation, in Proceedings of the 2010 International Conference on Economics, Business and Management, Institute of Electrical and Electronic Engineers (IEEE) Research Publishing, Manila, Philippines, 2010.

[15] M. Blahová and M. Zelený, Effective strategic action: Exploring synergy sources of european and asian management systems, Human Systems Management 32(3) (2013), 155-170.

[16] M. Bourne, M. Kennerley and M. Franco-Santos, Managing through measures: A study of impact on performance, Journal of Manufacturing Technology Management 16(4) (2005), 373-395.

[17] M. Bourne, A. Pavlov, M. Franco-Santos, L. Lucianetti and M. Mura, Generating organisational performance, The contributing effects of performance measurement and human resource management practices, International Journal of Operations \& Production Management 33(11/12) (2013), 1599-1622.

[18] M. Bromwich and A. Bhimani, Management Accounting: Evolution not Revolution, London: CIMA, 1989.

[19] M. Busi and U.S. Bititci, Collaborative performance management: Present gaps and future research, International Journal of Operations \& Production Management 55(1) (2006), 7-25.

[20] Ch. Carr and M. Pudelko, Convergence of management practices in strategy, finance and HRM between the USA, Japan and Germany, International Journal of Cross Cultural Management 6(1) (2006), 75-100.

[21] R.H. Chenhall, Reliance on manufacturing performance measures, total quality management and organizational performance, Management Accounting Research 8(2) (1997), $187-206$.
[22] P. Cocca and M. Alberti, A framework to assess performance measurement systems in SMEs, International Journal of Productivity and Performance Management 59(2) (2010), 186-200.

[23] G. Cokins, Performance Management, New Jersey: John Wiley \& Sons, 2009.

[24] S. Collinson and A.M. Rugman, The regional nature of japanese multinational business, Journal of International Business Studies 39(2) (2008), 215-230.

[25] R. Cooper, Kyocera Corporation: The Amoeba Management System, Boston: Harvard Business School, 1994.

[26] R. Cooper, When Lean Enterprises Collide, Boston: Harvard Business School Press, 1995.

[27] S.J. Daniel, W.D. Reitsperger and K. Morse, A longitudinal study of japanese manufacturing strategies for quality, JIT and flexibility, Asian Business and Management 8(3) (2009), 325-356.

[28] A. Delios and P.W. Beamish, Regional and global strategies of japanese firms, Management International Review 45(1) (2005), 19-36.

[29] A. Delios and W.J. Henisz, Policy uncertainty and the sequence of entry by japanese firms 1980-1998, Journal of International Business Studies 34(3) (2003), 227-241.

[30] P.F. Drucker, What we can learn from japanese management, Harvard Business Review 49 (1971), 110-122.

[31] R. Farrell, N. Gaston and J.-E. Sturm, Determinants of Japan's foreign direct investment: An industry and country panel study, 1984-1998, Journal of Japanese International Economies 18(2) (2004), 161-182.

[32] P. Firkola, Japanese management practices past and present, Economic Journal of Hokkaido University 35 (2006), 115-130.

[33] G. Foster and C. Horngren, Flexible manufacturing systems: Cost management and cost accounting implications, Journal of Cost Management 2(3) (1988), 16-24.

[34] F. Franceschini, M. Galetto and E. Turina, Techniques for impact evaluation of performance measurement systems, International Journal of Quality \& Reliability Management 30(2) (2013), 197-220.

[35] M. Franco-Santos, M. Kennerley, P. Micheli, V. Martinez, S. Mason, B. Marr, D. Gray and A. Neely, Towards a definition of a business performance measurement system, International Journal of Operations \& Production Management 27(8) (2007), 784-801.

[36] M. Franco-Santos, L. Lucianetti and M. Bourne, Contemporary performance measurement systems: A review of their consequences and a framework for research, Management Accounting Research 23 (2012), 79-119.

[37] N. Furuya, M.J. Stevens, A. Bird, G. Oddou and M. Mendenhall, Managing the learning and transfer of global management competence: Antecedents and outcomes of japanese repatriation effectiveness, Journal of International Business Studies 40(2) (2009), 200-215.

[38] P. Haghirian, Innovation and Change in Japanese Management, Hampshire: Palgrave Macmillan, 2010.

[39] P. Haghirian, R.R. Sinkovics and V. Bamiatzi, Japan - new business opportunities in an established market, Global Business and Organizational Excellence 28(1) (2008), 51-61. 
[40] P.A. Hall and D. Soskice, Varieties of Capitalism: The Institutional Foundations of Comparative Advantage, Oxford: Oxford University Press, 2001.

[41] K. Hamada and Y. Monden, Profit management at kyocera corporation: The amoeba system, in Japanese Management Accounting: A World Class Approach to Profit Management, Y. Monden, M. Sakurai, eds, Cambridge: Productivity Press, 1989, pp. 197-210.

[42] R.H. Hayes, Why japanese factories work, Harvard Business Review 59 (1981), 56-66

[43] T. Hiromoto, Management accounting system as a micromacro loop, The Hitotsubashi Review 134(5) (2005), 828-858.

[44] S.A. Horn and A.R. Cross, Japanese management at a crossroads? The changing role of china in the transformation of corporate Japan, Asia Pacific Business Review 15(3) (2009), 285-308.

[45] T. Iida and J. Morris, Farewell to the salaryman? The changing roles and work of middle managers in Japan, International Journal of Human Resource Management 19(6) (2008), 1072-1087.

[46] K. Inamori, Respect the Devine and Love People, San Diego: University of San Diego Press, 1999.

[47] H. Itakura, Business management of japanese corporations in China: Focusing on the China-Japan comparative study of leadership and organizational culture, Journal of Transnational Management 16 (2011), 221-238.

[48] S.M. Jacoby, Business and society in Japan and the United States, British Journal of Industrial Relations 43(4) (2005), 617-634.

[49] K. Kato, M. Li and D.J. Skinner, Is Japan Really a "Buy"? The Corporate Governance, Cash Holdings, and Economic Performance of Japanese Companies, Center on Japanese Economy and Business Working Papers, New York: Center on Japanese Economy and Business, Columbia University, 2012.

[50] K. Kato, D.J. Skinner and M. Kunimura, Management forecast in Japan: An empirical study of forecasts that are effectively mandated, The Accounting Review 84(5) (2009), 1575-1606.

[51] A.B. Keizer, M. Umemura, R. Delbridge and G. Morgan, Japanese Management 20 Years On: The Contemporary Relevance of Japanese Management Practices, AIM Executive Review, 2012.

[52] Y. Kijima, Y. Sano, T. Watanabe, H. Kawai, H. Narita, Y. Sakurai, S. Horiuchi, K. Tahiro, N. Manabe and T. Kishida, Investigating the Relationship Between Management Accounting and Organization Culture, Tokyo: Chuo Daigaku Shuppanbu, 2006.

[53] K. Kiyota and S. Urata, The Role of Multinational Firms in International Trade: The Case of Japan, Japan and The World Economy, Working Paper 560, Research seminar in international economics, University of Michigan, 2007.

[54] D. Lehmberg, Human resources practices and the labour market in Japan, Harvard Business Review, 2013, retrieved March 3, 2014, from http://hbr.org/product/ human-resources-practices-and-the-labour-market-in-japan/ an/W13342-PDF-ENG.
[55] D. Lehmberg, Ch. Dhanaraj and A. Funai, What do we make of Japan? Myths and realities, Business Horizons 56 (2) (2013), 219-229.

[56] E. Magoshi and E. Chang, Diversity management and the effects on employees' organizational commitment: Evidence from Japan and Korea, Journal of World Business 44 (2009), $31-40$.

[57] S. Makino, P.W. Beamish and N.B. Zhao, The characteristics and performance of japanese FDI in less developed and developed countries, Journal of World Business 39 (2004), 377-392.

[58] B. Marr, Managing and Delivering Performance, How Government, Public Sector and Not-for-profit Organizations Can Measure and Manage What Really Matters, New York: Routledge, 2009.

[59] B. Marr, Key Performance Indicators, The 75 Measures Every Manager Needs to Know, Harlow: Pearson Education Limited, 2012.

[60] L. Mia, Just-in-time manufacturing, management accounting systems and profitability, Accounting, Organizations and Society 30(2) (2000), 137-151.

[61] P. Micheli, M. Mura and M. Agliati, Exploring the roles of performance measurement systems in strategy implementation, International Journal of Operations \& Production Management 31(10) (2011), 1115-1139.

[62] H. Miya, Micro-profit center system for empowerment: A case study of the amoeba system at the Kyocera corporation, Gakushuin Economic Papers 2(35) (1998), 105-115.

[63] H. Miyoshi and Y. Nakata, Have Japanese Firms Changed? Hampshire: Palgrave Macmillan, 2010.

[64] J. Morris, J. Hassard and L. McCann, New organizational forms, human resource management and structural convergence? A study of japanese organizations, Organization Studies 27(10) (2006), 1485-1511.

[65] National Institute of Population and Social Security Research, Population Projection for Japan, 2012.

[66] A. Neely, Business Performance Measurement, Unifying Theory and Integrating Practice, Cambridge: Cambridge University Press, 2007.

[67] S.S. Nudurupati, U.S. Bititci, V. Kumar and F.T.S. Chan, State of the art literature review on performance measurement, Computers \& Industrial Engineering 60 (2011), 279-290.

[68] T. Numagami, M. Kawabe and T. Kato, Organizational deadweight: Learning from Japan, Academy of Management Perspective 24(4) (2010), 25-45.

[69] OECD, Education at a Glance: OECD Indicators 2006, Paris: Organization for Economic Co-operation and Development, 2011.

[70] OECD, OECD Economic Surveys JAPAN, Paris: Organization for Economic Co-operation and Development, 2013.

[71] Y.S. Pak and Y.-R. Park, Characteristics of japanese FDI in the east and the west: Understanding the strategic motives of japanese investment, Journal of World Business 40(3) (2005), 254-266.

[72] R.T. Pascale and A.G. Athos, The Art of Japanese Management, London: Penguin, 1982 
[73] S. Perera, G. Harrison and M. Poole, Customer-focused manufacturing strategy and the use of operations-based non-financial performance measures: A research note, Accounting, Organizations and Society 22(6) (1997), 557-572.

[74] A.Ch. Phan, A.B. Abdallah and Y. Matsui, Quality management practices and competitive performance: Empirical evidence from japanese manufacturing companies, International Journal of Production Economics 133 (2011), 518-529.

[75] M.E. Porter, H. Takeuchi and M. Sakakibara, Can Japan Compete? New York: Basic Books, 2000.

[76] V. Pucik, Promotion patterns in a japanese company, Columbia Journal of World Business 20(3) (1985), 73-79.

[77] M. Pudelko, The End of Japanese-Style Management? Long Range Planning 42 (2009), 439-462.

[78] M. Pudelko and R. Haak, Japanese Management, The Search for a New Balance between Continuity and Change, Hampshire: Palgrave Macmillan, 2005.

[79] M. Pudelko and A. Harzing, Japanese Human Resource Management Inspirations from Abroad and Current Trends of Change, Challenges of Human Resource Management in Japan, Routledge Contemporary Japan Series, 2011.

[80] M. Pudelko and M.E. Mendenhall, What western executives need to know about current japanese management practices, Organizational Dynamics 36(3) (2007), 274-287.

[81] J.E. Rehfeld, What working for a japanese company taught me, Harvard Business Review 68 (1990), 167-176.

[82] J. Renshaw, Kimono in the Board Room, Oxford: Oxford University Press, 1999.

[83] K. Sakai, The feudal world of japanese manufacturing, Harvard Business Review 68 (1990), 38-49.

[84] T. Sakikawa, Transforming Japanese Workplaces, Hampshire: Palgrave Macmillan, 2012.

[85] B. Salsberg, The new japanese consumer, McKinsey Quarterly, 2010, retrieved January 10, 2014, from http://www. mckinsey.com/insights/consumer_and_retail/the_new_japane se_consumer.

[86] U. Schaede, Show Me the Money: Japan's Most Profitable Companies in the 2000s, Working Papers, San Diego: School of International Relations and Pacific Studies, University of California, 2011.

[87] R.J. Schonberger, Japanese Manufacturing Techniques: Nine Hidden Lessons in Simplicity, New York: Free Press, 1982.

[88] R.J. Schonberger, Japanese production management: An evolution - with mixed success, Journal of Operations Management 25 (2007), 403-419.

[89] K. Shirahada, and K. Niwa, An Activation-Process Management for Technical Organizations and Its Application to Japanese Automobile Company, PICMET 2009-2009 Portland International Conference on Management of Engineering and Technology, Portland, 2009, pp. 2133-2143.

[90] N.S. Siddharthan and M.L. Lakhera, Foreign direct investment and location advantages: Japanese perceptions of India compared to China and ASEAN, Journal of International and Area Studies 12(1) (2005), 99-110.
[91] S.D. Sousa, E.M. Aspinwall and A.G. Rodrigues, Performance measures in english small and medium enterprises: Survey results, Benchmarking: An International Journal 13(1/2) (2006), 120-134.

[92] D. Staley, Japan's uncertain future, The Futurist, (2002), 48-53.

[93] C. Süssmuth-Dyckerhoff, J. Wang and J. Chen, Women Matter: An Asian Perspective, Harnessing Female Talent to Raise Corporate Performance, McKinsey \& Company, 2012.

[94] S. Taylor, Review - kimono in the boardroom: The invisible evolution of japanese women managers, The Academy of Management Review 25(3) (2000), 670-672.

[95] S. Tejima, Japanese FDI, the implications of "Hollowing Out" on the technological development of host countries, International Business Review 9 (2000), 555-570.

[96] E. Tomiura, Technological capability and FDI in Asia: Firmlevel relationships among japanese manufacturers, Asian Economic Journal 19(3) (2005), 273-289.

[97] L. Vives, K. Asakawa and S. Svejenova, Innovation and the multinational enterprise, Advances in International Management, 23 (2010), 497-523.

[98] R. Worthley, B. MacNab, R. Brislin, K. Ito and E.L. Rose, Workforce motivation in Japan: An examination of gender differences and management perceptions, The International Journal of Human Resource Management 20 (7) (2009), 1503-1520.

[99] Ch.Y. Yang, Demystifying japanese management practices, Harvard Business Review 62(6) (1984), 172-182.

[100] E. Yoshida, K. Fukushima and T. Senoo, Management accounting in japanese firms: A descriptive study, Corporate Accounting 61(10) (2009), 134-140.

[101] T. Yoshida, K. Yashiro and Y. Suzuki, Intercultural communication skills: What japanese businesses today need, International Journal of Intercultural Relations 37 (2013), 72-85.

[102] Y. Yoshida and H. Ito, How do the Asian economies compete with Japan in the US market? Is China exceptional? A triangular trade approach, Asia Pacific Business Review 12(3) (2006), 285-307.

[103] S.M. Young and F.H. Selto, Explaining cross-sectional workgroup performance differences in a JIT facility: A critical appraisal of a field-based study, Journal of Management Accounting Research 5 (1993), 300-326.

[104] M. Yuasa, Japanese women in management: Getting closer to "Realities" in Japan, Asia Pacific Business Review 11(2) (2005), 195-211.

[105] M. Zelený, Human Systems Management: Integrating Knowledge, Management and Systems, Singapore: World Scientific Publishing, 2005.

[106] M. Zelený, Machine/organism dichotomy and free-market economics: Crisis or transformation? Human Systems Management 29(4) (2010), 191-204.

[107] M. Zelený, Crisis and transformation: On the corso and ricorso of human systems, Human Systems Management 31(1) (2012), 49-63. 